\title{
Double-Shell Tank Space Analysis of Hanford Site Operating Scenarios
}

Prepared for the U.S. Department of Energy Assistant Secretary for Defense Programs

\footnotetext{
(2) Westinghouse

W Hanford Company Richland, Washington

Hanford Operations and Engineering Contractor for the

U.S. Department of Energy under Contract DE-AC06-87RL10930
} 


\section{DISCLAIMER}

This report was prepared as an account of work sponsored by an agency of the United States Government. Neither the United States Government nor any agency thereof, nor any of their employees, nor any of their contractors, subcontractors or their employees, makes any warranty, express or implied. or assumes any legal liability or responsibility for the accuracy. completeness, or any third party's use or the results of such use of any information, apparatus, product, or process disclosed, or represents that its use would not infringe privately owned rights. Reference herein to any specific commercial product, process, or service by trade name. trademark, manufacturer, or otherwise, does not necessarily constitute or imply its endorsement, recommendation, or favoring by the United States Government or any agency thereof or its contractois or subcontractors. The views and opinions of authors expressed herein do not necessarily state or seflect those of the United States Government or any agency thereol.

\section{Available from}

U.S. Department of Commerce

National Technical Information Service

5285 Port Royal Road

Springfield, VA 22161

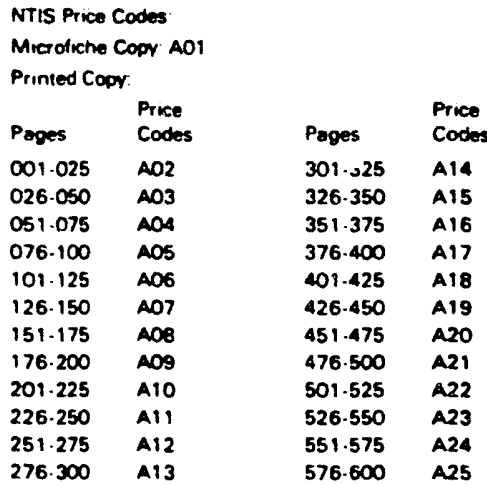

Printed in the Unned States of America 


\section{Double-Shell Tank Space Analysis of Hanford Site Operating Scenarios}

D. E. McKenney

D. C. Riley

R. L. Shaver

J. N. Strode

Date Published

January 1990

Prepared for the U.S. Department of Energy Assistant Secretary for Defense Programs

(W) Westinghouse

P.O. Box 1970

Hanford Company Richland, Washington 99352

Hanford Operations and Engineering Contractor for the

U.S. Department of Energy under Contract DE-AC06-87RL10930 


\title{
DOUBLE-SHELL TANK SPACE ANALYSIS OF HANFORD SITE OPERATING SCENARIOS
}

\author{
D. E. McKenney
}

\begin{abstract}
Several operating cases were evaluated to determine the Hanford Site activities that can be supported given two 242-A Evaporator operating assumptions: (1) the evaporator does not restart and (2) the evaporator does not restart until December 1990 . These cases included variations in production facility operation and Hanford Federal Facility Agreement and Consent Order (Tri-Party Agreement) commitments. The cases that evaluated the "no evaporator restart" operating assumptions determined that even the minimal double-shell tank waste generating activities cannot be supported. For the minimal waste generation rate, double-shell tank space would be depleted by December 1991. The cases that evaluated the evaporator restart would support all production missions with the exception of the plutonium-uranium extraction (PUREX) processing. A delay in the evaporator restart and/or increased waste generation could significantly impact the above conclusions. Actions to reduce waste generation rates, minimize stored volumes in the double-shell tanks, and optimize use of double-shell tanks must be pursued.
\end{abstract}




\section{EXECUTIVE SUMMARY}

Several operating cases were evaluated to determine the Hanford Site activities that can be supported given two 242-A Evaporator operating assumptions: (1) the evaporator does not restart and (2) the evaporator does not restart until December 1990. These cases included variations in production facility operating plans and Hanford Federal Facility Agreement and Consent Order [Tri-Party Agreement (TPA)] commitments.

The cases that evaluated the "no evaporator restart" operating assumptions determined that even minimum double-shell tank (DST) waste generating activities cannot be supported for an extended period of time without the evaporator. At best, DST space will be sufficient to accept wastes generated onsite until December 1991. Restart of the evaporator or complete shutdown of onsite facilities will be required before this date. Complete shutdown might involve violation of operational safety requirements and/or environmental release limits. Waste management activities, such as single-shell tank stabilization and waste pretreatment, cannot be supported.

Evaluation of the cases that included the December 1990 evaporator restart resulted in more positive results. If the restart of 242-A Evaporator operations is delayed until December 1990, site activities can be conducted as follows:

- Cleanout of the existing inventory in the Plutonium-Uranium Extraction (PUREX) Facility can be performed. This facility stabilization campangn is required to remove existing nuclear material inventories from the facility and to place the facility in the most stable standby condition until production operations can resume.

- Soil column wastes (PUREX Facility ammonia scrubber wastes and PUREX Facility process condensate) can be received in the DSTs during the stabilization campaign. These wastes cannot be received in the DSTs after production operations resume.

- After evaporator restart, processing of fuels in the PUREX Facility can proceed at 500 metric tons of uranium (MTU) per year.

- The Plutonium Finishing Plant can operate. This will include both Plutonium Reclamation Facility and Remote Mechanical "C" (RMC) Line operations at 100 days per year for each.

- TPA commitments, such as Grout Treatment Facility operations, pretreatment operations, single-shell tank stabilization, and Hanford Waste Vitrification Facility startup, can be pursued on schedules consistent with TPA commitment dates.

Assuming PUREX Facility restart is delayed until after the evaporator restart, a slip of approximately 1 month from the December 1990 242-A Evaporator restart date can be accommodated. If the decision is made to begin fuel processing before evaporator restart, some of the above activities will have to be curtailed. A delay in the evaporator restart date will also impact the above activities.

Site performance, relative to the assumptions used as a basis for developing this operating case, must be carefully monitored. Significant deviations from the assumptions will impact the conclusions made. 
Actions to reduce waste generation rates, minimize stored volumes in the DSTs, and optimize use of DSTs must still be pursued. Such actions will help increase the mission scope that can be supported in light of constrained DST space availability. 


\section{LIST OF TERMS}

$\begin{array}{ll}\bullet & \text { DSSF } \\ \bullet & \text { DST } \\ \bullet & \text { Ecology } \\ \bullet & \text { GTF } \\ \bullet & \text { MWVI } \\ \bullet & \text { PFP } \\ \bullet & \text { PUREX } \\ \bullet & \text { RCRA } \\ \bullet & \text { SST } \\ & \text { TPA }\end{array}$

double-shell slurry feed

double-shell tank

Washington State Department of Ecology

fiscal year

Grout Treatment Facility

Hanford Waste Vitrification Plant

metric tons of uranium

Plutonium Finishing Plant

Plutonium-Uranium Extraction

Resource Conservation and Recovery Act

Remote Mechanical " $\mathrm{C}$ "

single-shell tank

Tri-Party Agreement (formally known as the Hanford Federal

Facility Agreement and Consent Order) 
WHC-EP-0286

This page intentionally left blank.

viii 


\section{CONTENTS}

1.0 Introduction $\ldots \ldots \ldots \ldots \ldots \ldots \ldots \ldots \ldots \ldots \ldots \ldots \ldots \ldots \ldots \ldots \ldots \ldots \ldots \ldots \ldots \ldots \ldots \ldots \ldots \ldots, 1$

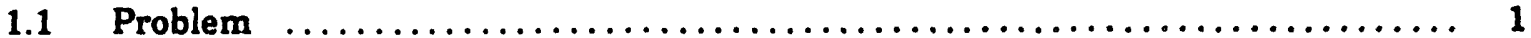

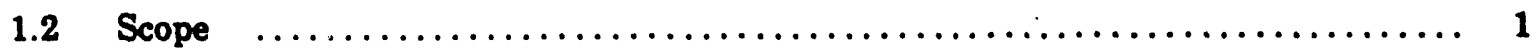

1.3 Background $\ldots \ldots \ldots \ldots \ldots \ldots \ldots \ldots \ldots \ldots \ldots \ldots \ldots \ldots \ldots \ldots \ldots \ldots \ldots, 2$

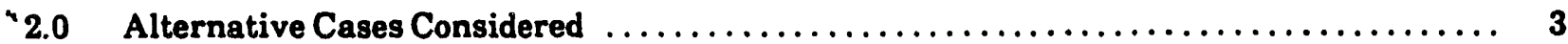

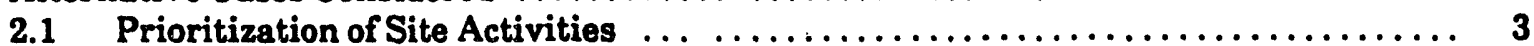

2.2 Case Cescriptions and Waste Volur.e Projections (No Evaporator Restart) ....... 3

2.2.1 Baseline (Case 1A) .................................. 4

2.2.2 PUREX Facility Stabilization (Case 1B) $\ldots \ldots \ldots \ldots \ldots \ldots \ldots \ldots \ldots \ldots, 6$

2.2.3 Tri-Party Agreement Support (Case 1C) $\ldots \ldots \ldots \ldots \ldots \ldots \ldots \ldots \ldots, 8$

2.2.4 Plutonium Finishing Plant Operation (Case 1D) $\ldots \ldots \ldots \ldots \ldots \ldots \ldots, 10$

2.2.5 PUREX Facility Operation (Case 1E) $\ldots \ldots \ldots \ldots \ldots \ldots \ldots \ldots \ldots \ldots \ldots \ldots$

2.3 Case Descriptions and Waste Volume Projections (December 1990

Evaporator Restart) ............................... 14

2.3.1 PUREX Facility Operation and 242-A Evaporator Restart (Case 2A) ...... 14

2.3.2 Plutonium Finishing Plant Operations and 242-A Evaporator

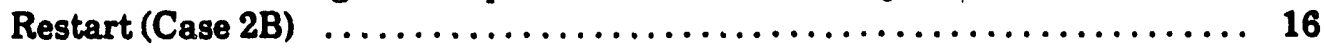

2.3.3 Modified Production Facility Operations and 242-A Evaporator Restart (Case 2C) $\ldots \ldots \ldots \ldots \ldots \ldots \ldots \ldots \ldots \ldots, 18$

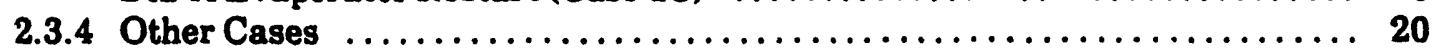

3.0 References $\quad \ldots \ldots \ldots \ldots \ldots \ldots \ldots \ldots \ldots \ldots \ldots \ldots \ldots \ldots \ldots \ldots \ldots \ldots \ldots \ldots, 21$

Appendix:

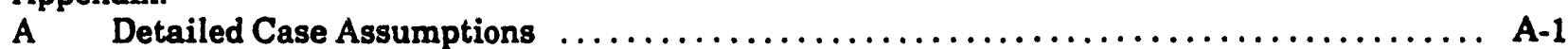


WHC-EP-0286

\section{LIST OF FIGURES}

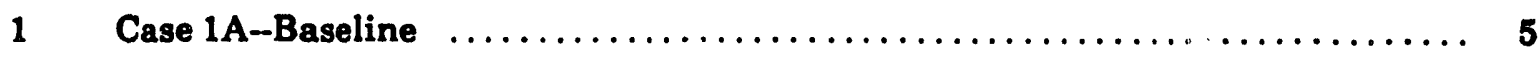

2 Case 1B--PUREX Facility Stabilization Waste $\ldots \ldots \ldots \ldots \ldots \ldots \ldots \ldots \ldots, 7$

3 Case 1C--Support to Tri-Party Agreement $\ldots \ldots \ldots \ldots \ldots \ldots \ldots \ldots \ldots \ldots \ldots \ldots$

4 Case 1D--Plutonium Finishing Plant Operation $\ldots \ldots \ldots \ldots \ldots \ldots \ldots \ldots \ldots, 11$

5 Case 1E-.PUREX Facility Operation $\ldots \ldots \ldots \ldots \ldots \ldots \ldots \ldots \ldots \ldots \ldots \ldots \ldots \ldots$

6 Case 2A--PUREX Facility Operation and 242-A Evaporator Restart .......... 15

7 Case 2B--Plutonium Finishing Plant Operations and 242-A Evaporator Restart .. 17

8 Case 2C--Modified Production Facility Operations and 242-A Evaporator Restart $\ldots \ldots \ldots \ldots \ldots \ldots \ldots \ldots \ldots \ldots \ldots \ldots \ldots \ldots \ldots . \ldots \ldots$ 


\section{DOUBLE-SHELL TANK SPACE ANALYSIS OF HANFORD SITE OPERATING SCENARIOS}

\subsection{INTRODUCTION}

- Defense waste management and production activities at the Hanford Site result in the generation of liquid wastes, some of which can be discharged to the environment and some of which cannot be discharged to the environment or disposed of without additional treatment. Those that cannot be discharged to the environment are stored in double-shell tanks (DST) to await eventual disposal. Depending on waste characteristics and pretreatment requirements, disposal of these tank wastes may consist of either vitrification and geologic disposal or grouting and rasar-surface disposal on the Hanford Site.

There are currently 28 DSTs for storage of defense wastes on the Hanford Site. These tanks, of approximately 1-Mgal-capacity each, are critical to continued Hanford Site missions, including defense material production, site cleanup, waste pretreatment, and waste disposal operations.

Much effort is directed at reducing the volumes of waste stored in the DSTs. A major contributor to this waste volume reduction effort is the operation of the 242-A Evaporator, which is used to concentrate wastes and reduce stored volumes. The evaporator system is currently configured such that the treated process condensate (the water removed from the tank waste) is discharged to the soil column.

\subsection{PROBLEM}

In April 1989, the 242-A Evaporator operations were shut down because of concern that past practices may have generated Resource Conservation and Recovery Act (RCRA)-listed wastes that were discharged to DSTs. These wastes were then processed through the 242-A Evaporator, thus making it possible that the 242-A Evaporator process condensate was a dangerous waste (as it was derived from waste containing listed components). It is also possible that the 242-A Evaporator process condensate may be considered a characteristic dangerous waste.

If it is determined that the 242-A Evaporator process condensate is (was) a dangerous waste, then it is unlikely that use of the existing soil column disposal system can continue. Alternative storage, treatment, and disposal systems may have to be in place before the 242-A Evaporator can restart.

\subsection{SCOPE}

This report is limited to an evaluation of possible site operating cases, using the availability of DST space as the critical factor in determining the feasibility of the cases. Numerous variations in scope of the Hanford Site mission are evaluated, ranging from site shutdown (standby) to full production operations. Two 242-A Evaporator operating assumptions are evaluated: one in which the 242-A Evaporator does not restart and one in which 242-A Evaporator restarts in December 1990 (based on when a retention facility for the process condensate can be made available). 
WHC-EP-0286

\subsection{BACKGROUND}

Site operating cases are evaluated using the Defense Waste Management Waste Volume Projection System. Existing waste volume projections are used to develop the cases presented in this report, and averaging and estimating techniques are used to assess changes from these existing projections.

A detailed waste volume projection model run will be performed for the recommended case to "verify the conclusion contained within this report. The database and methodology used will be similar to those described in Strode (1989). 


\subsection{ALTERNATIVE CASES CONSIDERED}

Several site operating cases were evaluated to determine the scope of site activities that can be supported, given the possible delay in the restart of the 242-Evaporator. These operating cases are described below.

\section{'2.1 PRIORITIZATION OF SITE ACTIVITIES}

To develop operating scenarios, site activities must be prioritized. First, a baseline was developed that reflected the minimum anticipated tank space requirements. This baseline, when compared to available DST space (28 DSTs), is used to establish how much DST space is available for support of site activities. Prioritized site activities con then be used to develop operating scenarios.

Site activities, in order of perceived priority, are as follows.

- Plutonium-Uranium Extraction (PUREX) Fasility Stabilization--This activity is required to remove existing nuclear material inventories from the facivity and place the facility in the most stable standby condition until production operations resume. This activity is a requirement common to all nonbaseline cases evaluated.

- The Hanford Federal Facility Agreement and Consent Order (Tri-Party Agreement [TPA]) Commitments--These commitments are considered to be second only to the safety-related PUREX Facility stabilization activity. This includes commitments related to waste disposal activities, such as B Plant pretreatment operations, single-shell tank (SST) stabilization, and Hanford. Waste Vitrification Plant (HWVP) startup.

- Production Operations--Production operations, though important, are considered third priority relative to the preceding activities.

The operating cases, and the resulting waste volume projections for each case, are discussed in the following sections.

\subsection{CASE DESCRIPTIONS AND WASTE VOLUME PROJECTIONS (NO EVAPORATOR RESTART)}

The waste volume projection cases considered in this section assume that the 242-A Evaporator is not restarted. A baseline case is developed, and all subsequent cases represent incremental additions to the baseline. 


\subsubsection{Baseline (Case 1A)}

The baseline case represents the minimum DST space requirements (minimum waste generation) anticipated. The following major assumptions apply to this case.

- The 242-A Evaporator does not resume operations.

- Production facilities (PUREX Facility and Plutonium Finishing Plant [PFP]) do not operate. Waste generation is limited to only those wastes generated in standby conditions.

- SST stabilization activities are terminated. No additional saltwell liquid is pumped to the DSTs.

- Pretreatment operations are not pursuerd. The B Plant is not operated. The frout Treatment Facility (GTF) feeds resulting from pretreatment operations ame not generated.

- The GTF of srates for those "groutable" feeds currently in the DSTs. Dilute feeds and double-sheli slurry are not processed, for the reasons of unacceptably low waste loadings and lack of dedicated retrieval tank space, respectively.

A more detailed listing of assumptions for the baseline case is included in Appendix A.

The projected waste volumes for the baseline case are shown in Figure 1. This projection includes a number of comp onents: existing waste requiring pretreatment and retrieval before disposal, operational tariks, existing groutable inventory, existing dilute inventory, and standby wastes. Each of these components is discussed below.

The first component of the baseline case projection is the "existing waste requiring pretreatment and/or retrieval before disposal." These wastes, which include aging waste, complexed waste, doubleshell slurry, and neutralized cladding removal waste, cannot be disposed of as currently stored in DSTs. Retrieval and/or pretrea tment facilities have to be operational before these wastes can be disposed of in grout or glass.

The next component of the baseline case projection is the "operational" tank requirements. The operational tanks consist of a dedicated aging spare, a dedicated nonaging spare, an operational spare, and a dedicated grout feed DST (241-AP-102). An additional grout feed DST (241-AP-104) will be required when three or more grout campaigns are scheduled per year.

The "existing groutable inventory" component of the baseline case includes those tanks of doubleshell slurry feed (DSSF) or equivalent wastes that are suitable feeds to the GTF as currently stored. The "existing dilute inventory" is dilute waste currently stored in the DSTs. These are dilute wastes that have accumulated to date and are awaiting processing through the 242-A Evaporator. The final component of the baseline case projection is the "standby" waste. Standby wastes are those wastes generated in maintaining a facility in a condition amenable to restart of operations, but are not related to operational activities.

As can be seen in Figure 1, projected tank space requirements exceed available tank space in December 1991 for the baseline case. Restart of the evaporator or complete shutdown of site activities that contribute to DST waste volumes (even standby wastes would have to be eliminated) will be required by this date. Elimination of standby waste might involve violation of operational safety requirements and/or environmental release limits. Waste management activities, such as SST stabilization and waste pretreatment, cannot be pursued because of a lack of DST space. 
Figure 1. Case 1A--Baseline.

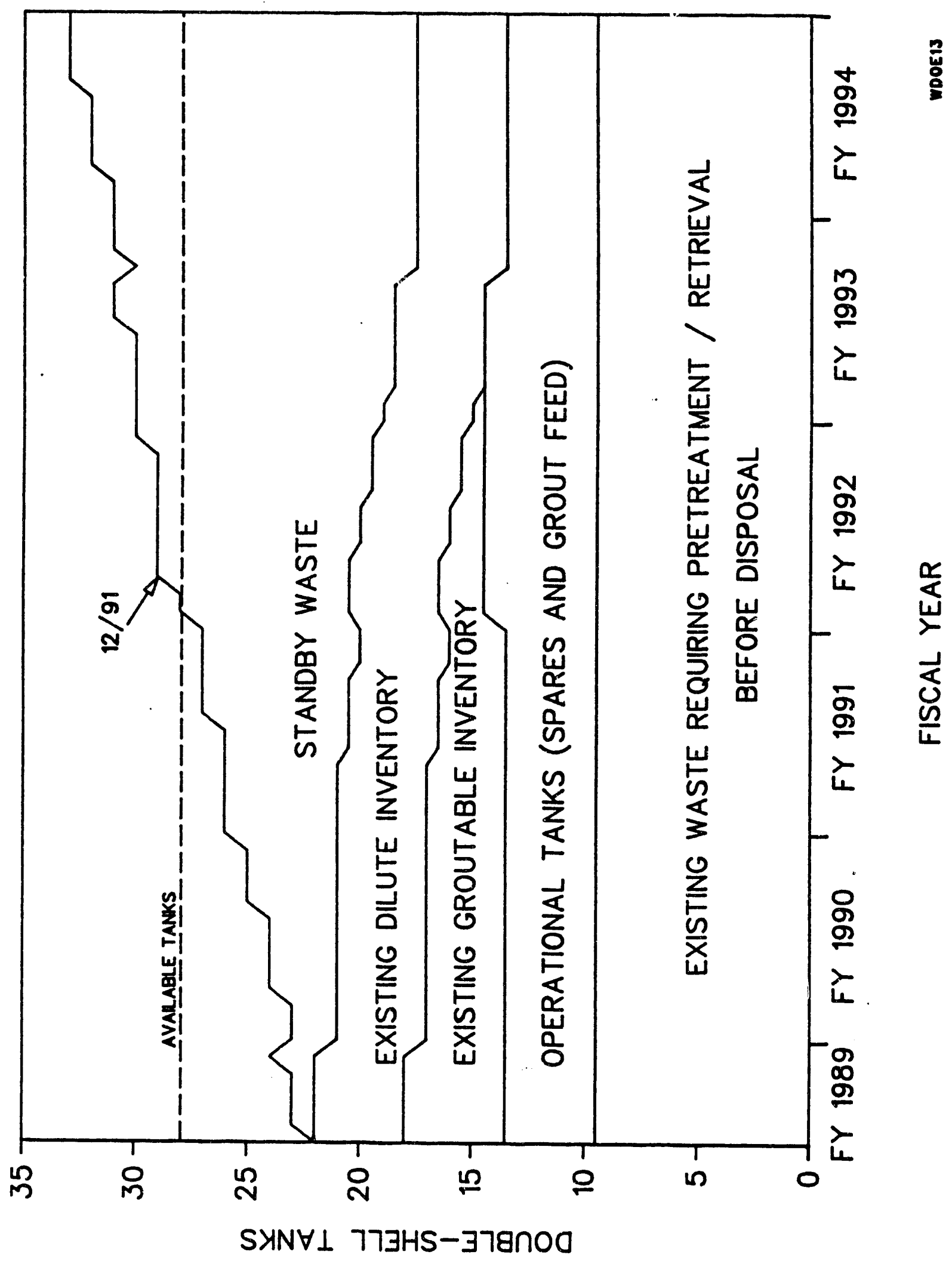




\subsubsection{PUREX Facility Stabilization (Case 1B)}

This case is the first increment above the baseline case. It is assumed that the existing inventory in the PUREX Facility will be processed. The stabilization of the PUREX Facility is considered to be a safety issue. Major assumptions, in addition to those listed for the baseline case, are as follows:

- The PUREX Facility operates to achieve stabilization (December 1989 and January 1990); no other production facilities are operated.

- The total waste generation from stabilization operations is $2.1 \mathrm{Mgal}$.

A more detailed listing of assumptions for the PUREX Facility stabilization case is included in Appendix A.

The results of this projection are shown in Figure 2. The projected DST space requirements exceed available DST space in April 1991. As with the previous case, site activities that contribute to DST waste volumes will have to be completely shut down by this date or the 242-A Evaporator must restart. Waste management activities, such as SST stabilization and waste pretreatment, cannot be pursued because of lack of DST space. 
Figure 2. Case 1B--PUREX Facility Stabilization Waste.

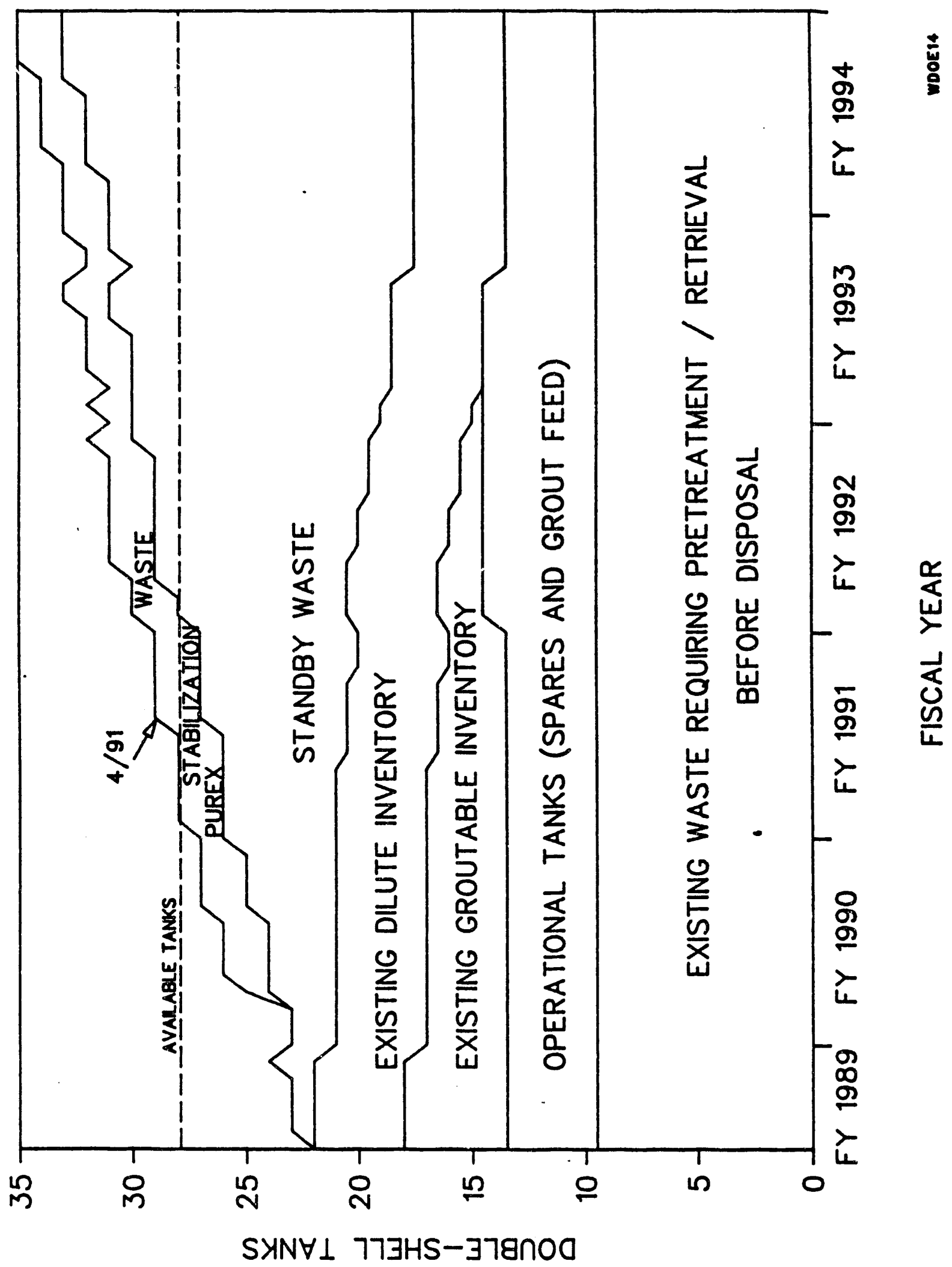




\subsubsection{Tri-Party Agreement Support (Case 1C)}

This case assumes that in addition to the PUREX Facility stabilization, TPA commitments will be pursued. Major assumptions of this case, in addition to those of the previous case, include the following:

- Pretreatment operations are pursued. The B Plant demonstration pretreatment operations start in October 1993.

- Stabilization of SSTs is pursued. The SSTs are stabilized (pumpable liquid transferred to DSTs) according to the TPA schedule.

- Although grout operations are pursued arcording to the TPA schedule, lack of suitable feed limits the number of campaigns to nine through fiscal year (FY) 1994. No evaporator operations and lack of DSTs for double-shell slurry retrieval are factors contributing to the lack of suitable GTF feed. Fourteen campaigns through FY 1994 were committed to as part of the TPA.

A more detailed listing of assumptions for the TPA support case is included in Appendix A.

The results of the projection are shown in Figure 3. Projected DST space requirements exceed available DST space in January 1991. This projection shows that without the evaporator, TPA milestones cannot be met and site activities that generate DST waste would have to be totally curtailed before January 1991. 
Figure 3. Case 1C--Support to Tri-Party Agreement.

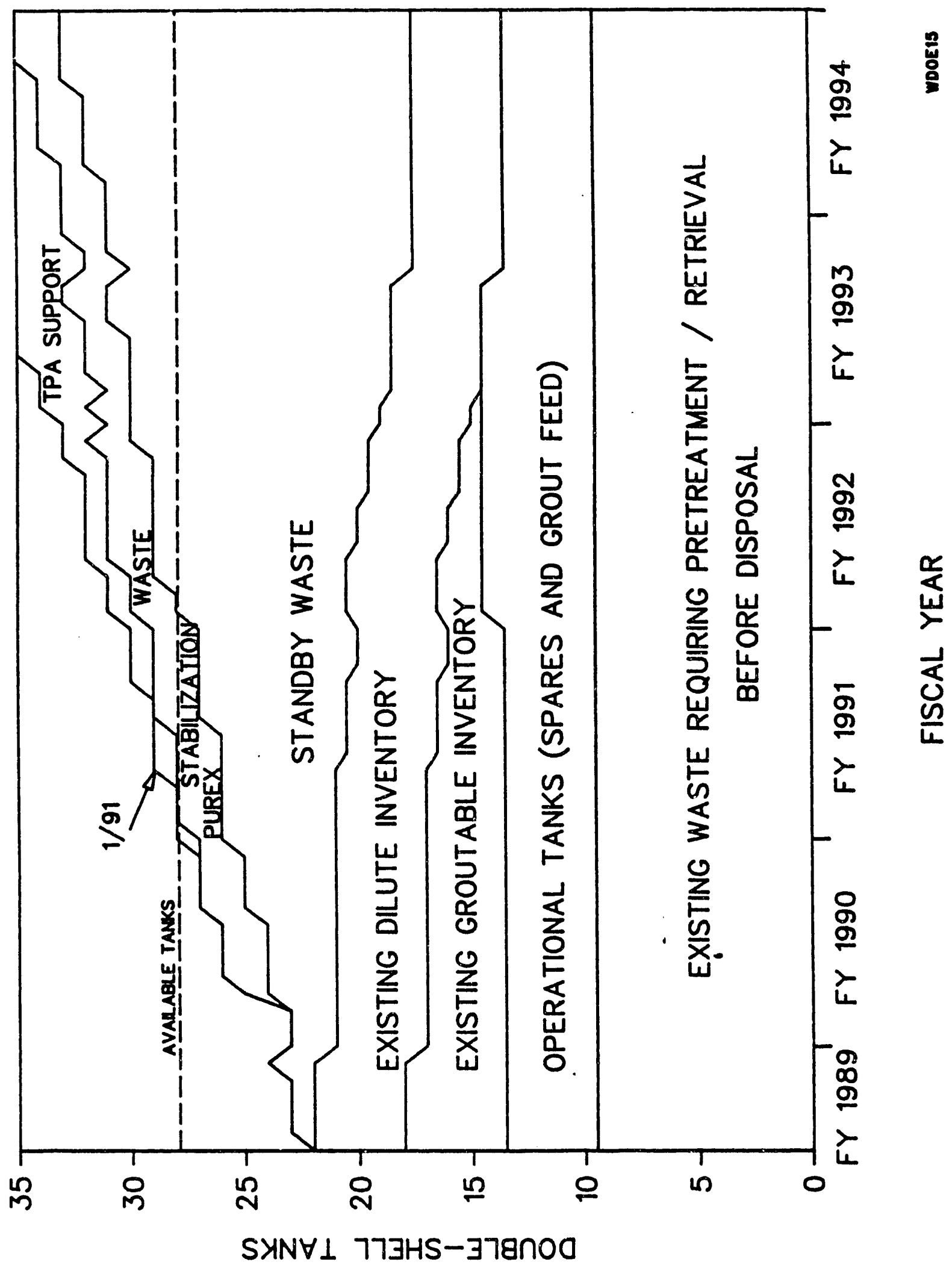




\subsubsection{Plutonium Finishing Plant Operation (Case 1D)}

This case builds on the previous case, but assumes that the PFP is also operated. Major assumptions for this case, in addition to those of the previous case, include the following:

- The PFP is assumed to operate (scrap recovery), and waste generation rates for the PFP were assumed to be the same as those assumed when the PFP and the PUREX Facility are both operating.

A more detailed listing of assumptions for the PFP operations case is included in Appendix A.

The results of the projection are shown in Figure 4. As can be seen in the figure, the projected DST space requirements exceed available DST space in December 1990. The impact of PFP operations on the projections is minimal. Conclusions are the same as for the previous case. 
WHC-EP-0286

Figure 4. Case 1D--Plutonium Finishing Plant Operation.

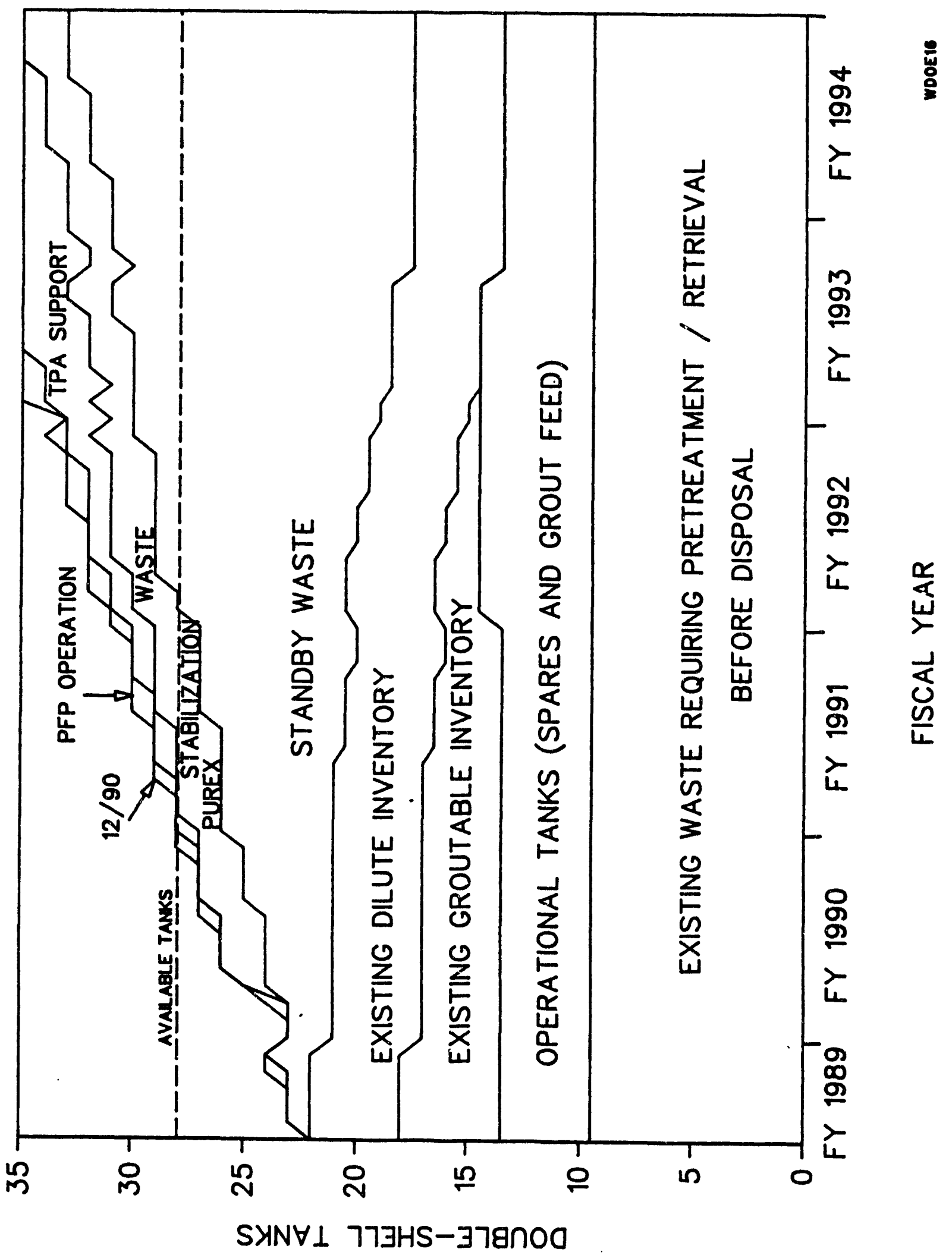




\subsubsection{PUREX Facility Operation (Case 1E)}

This case includes all of the assumptions of the previous case, plus the assumption that the PUREX Facility and the PFP operate according to planned chemical processing schedules. Major assumptions of this case, in addition to those of the previous case, include the following:

- Following PUREX Facility stabilization (December 1989 and January 1990), the PUREX Facility and PFP continue operations according to planned chemical processing schedules. The PUREX Facility process condensate is disposed of somewhere other than in the DSTs after facility stabilization.

A more detailed listing of assumptions for the PUREX Facility operations case is included in Appendix A.

The results of the projection are shown in Figure 5. Available DST space is exceeded by projected D!jT space requirements as early as April 1990. 
Figure 5. Case 1E--PUREX Facility Operation.

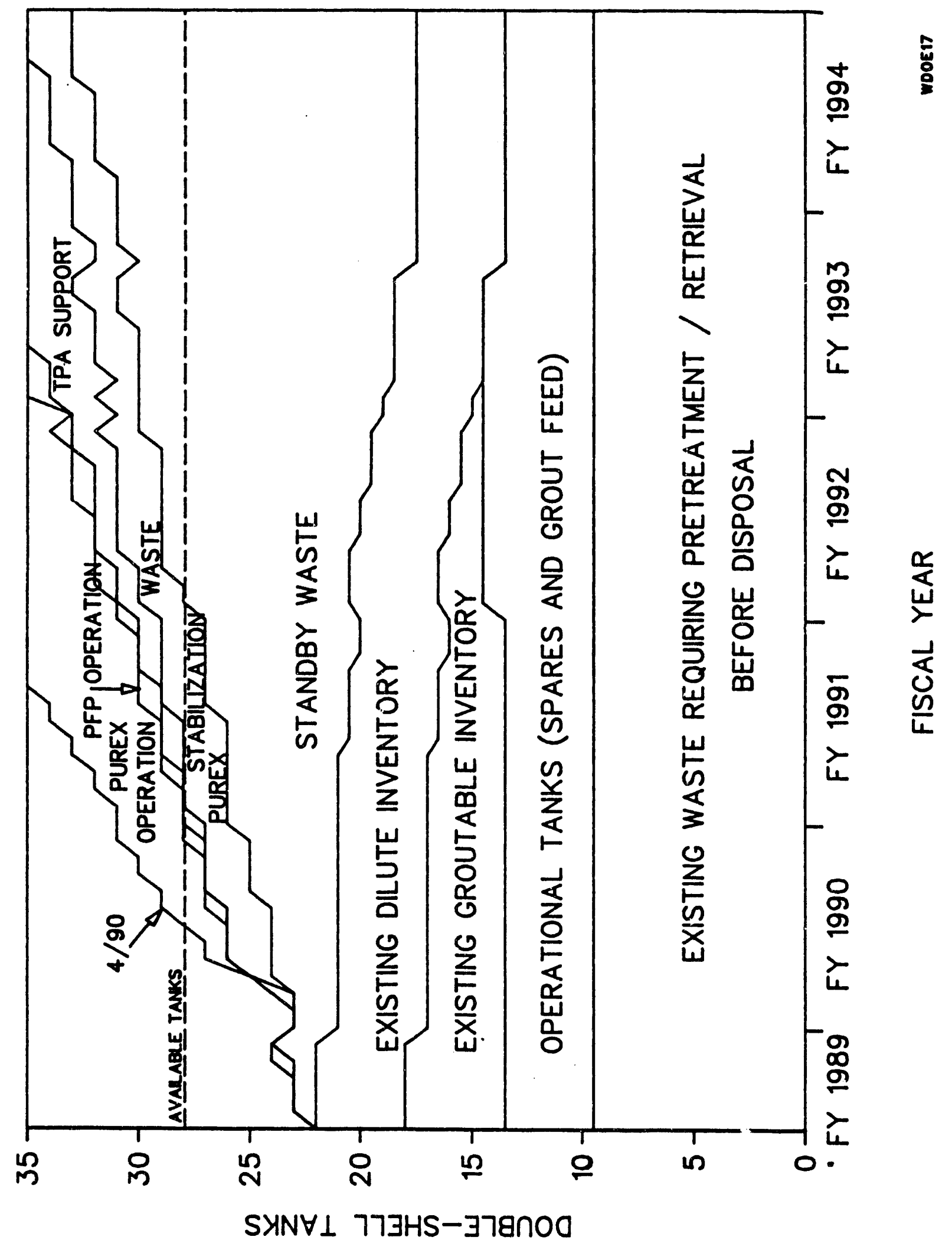




\subsection{CASE DESCRIPTIONS AND WASTE VOLUME PROJECTIONS (DECEMBER 1990 EVAPORATOR RESTART)}

The waste volume projection cases considered within this section assume that the 242-A Evaporator is restarted in December 1990. This evaporator restart date is based on recent discussions with the Washington State Department of Ecology (Ecology). These cases are the same as the previous cases, with the addition of the evaporator restart assumption.

\subsubsection{PUREX Facility Operation and 242-A Evaporator Restart (Case 2A)}

This projection has the same assumptions as Case 1E, with the exception that this case assumes an evaporator restart in December 1990.

A detailed listing of the assumptions for this case is included in Appendix A.

The results of the projection are shown in Figure 6. As can be seen in the figure, the projected DST space requirements exceed available DST space in April 1990. As expected, this date does not differ from Case 1E, because the evaporator restart date occurs after the date of projected DST space shortfall. The evaporator upgrades could be done in FY 1994. 
Figure 6. Case 2A--PUREX Facility Operation and 242-A Evaporator Restart.

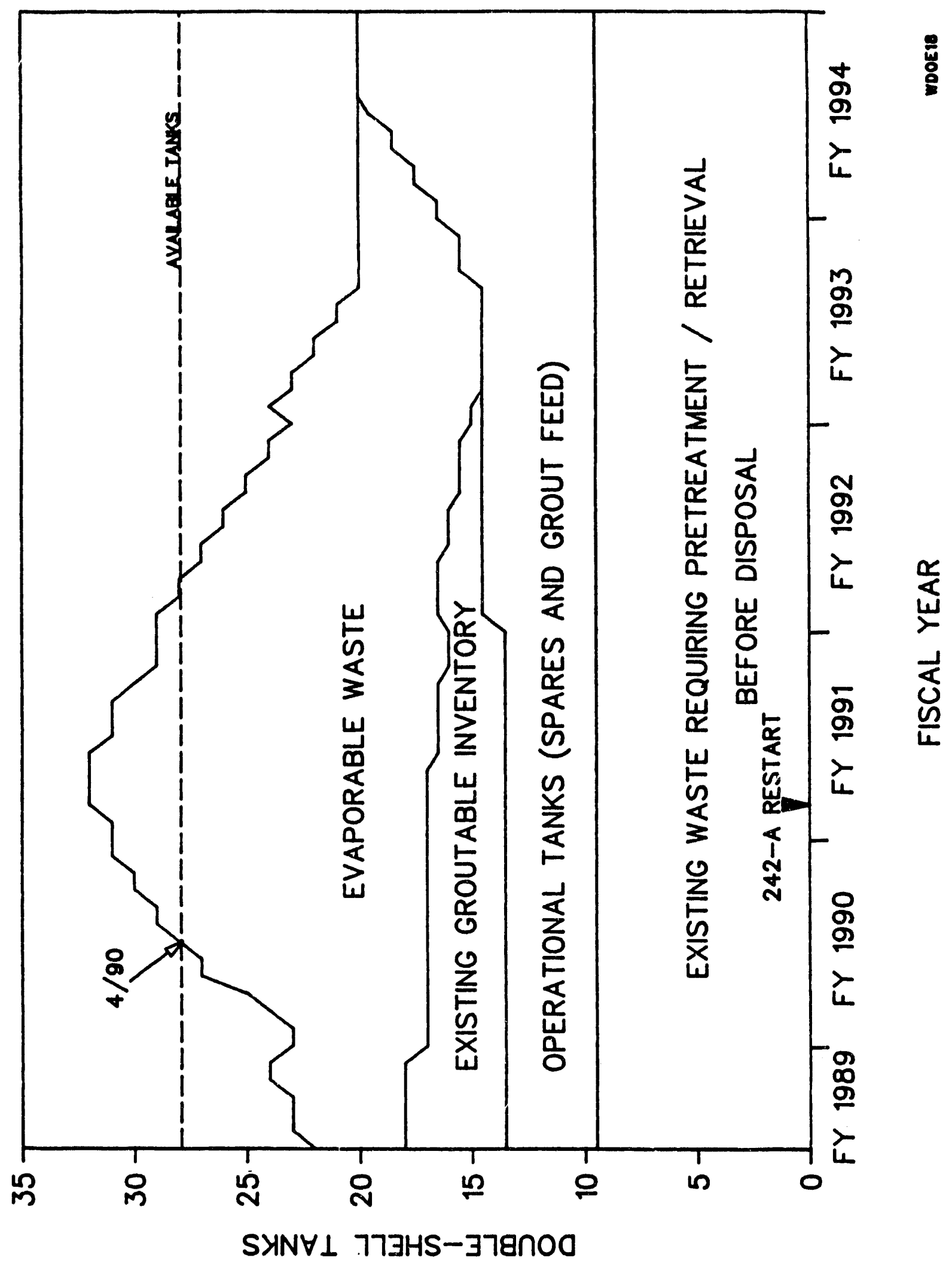


WHC-EP-0286

\subsubsection{Plutonium Finishing Plant Operations and 242-A Evaporator Restart (Case 2B)}

This projection has the same assumptions as previously evaluated Case 1D, with the exception that this case assumes an evaporator restart in December 1990.

A detailed listing of the assumptions for this case is included in Appendix $A$.

The results of the projection are shown in Figure 7. It is important to note that this projection indicates that PFP operations can be supported in this case in addition to PUREX Facility stabilization and TPA commitments. The evaporator is expected to process all of the dilute waste by the second quarter of FY 1994. 
Figure 7. Case 2B--Plutonium Finishing Plant Operations and 242-A Evaporator Restart.

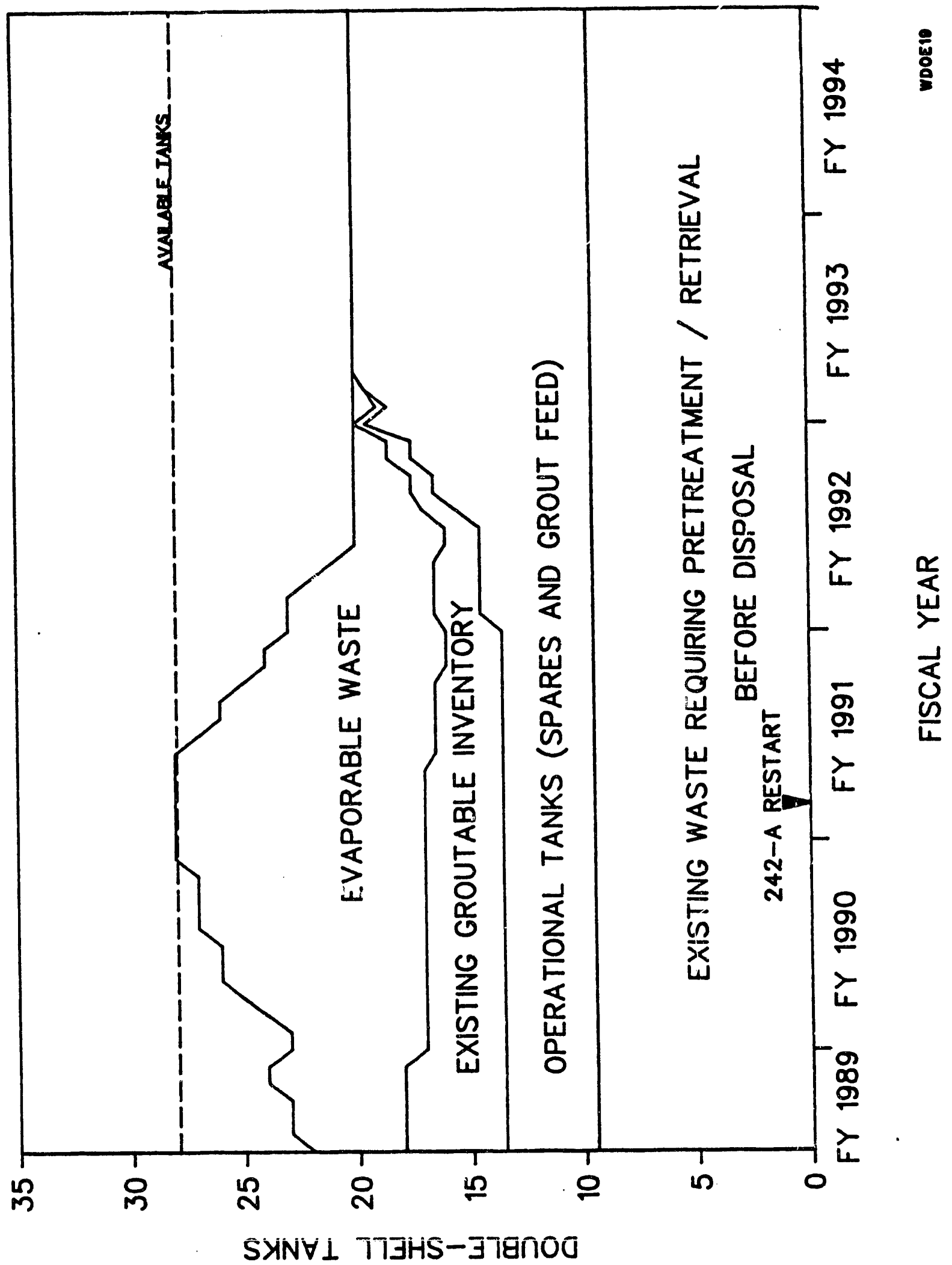




\section{WHC-EP-0286}

\subsubsection{Modified Production Facility Operations and 242-A Evaporator Restart (Case 2C)}

This projection has the same assumptions as Case 2A, with the following exceptions:

- The PFP operates 100 days per year for both the Plutonium Reclamation Facility and the Remote Mechanical "C" (RMC) Line.

- The processing of weapons grade fuel starts 1 month after evaporator restart.

- Processing of fuel in the PUREX Facility operates at 500 metric tons of uranium (MTU) per year after evaporator restart.

A more detailed listing of the assumptions for this case is included in Appendix A.

The results of this projection are shown in Figure 8. This case can be supported because DST space is sufficient to accommodate projected waste volumes. The evaporator upgrades can be done in FY 1994. 
Figure 8. Case 2C--Modified Production Facility Operations and 242-A Evaporator Restart.

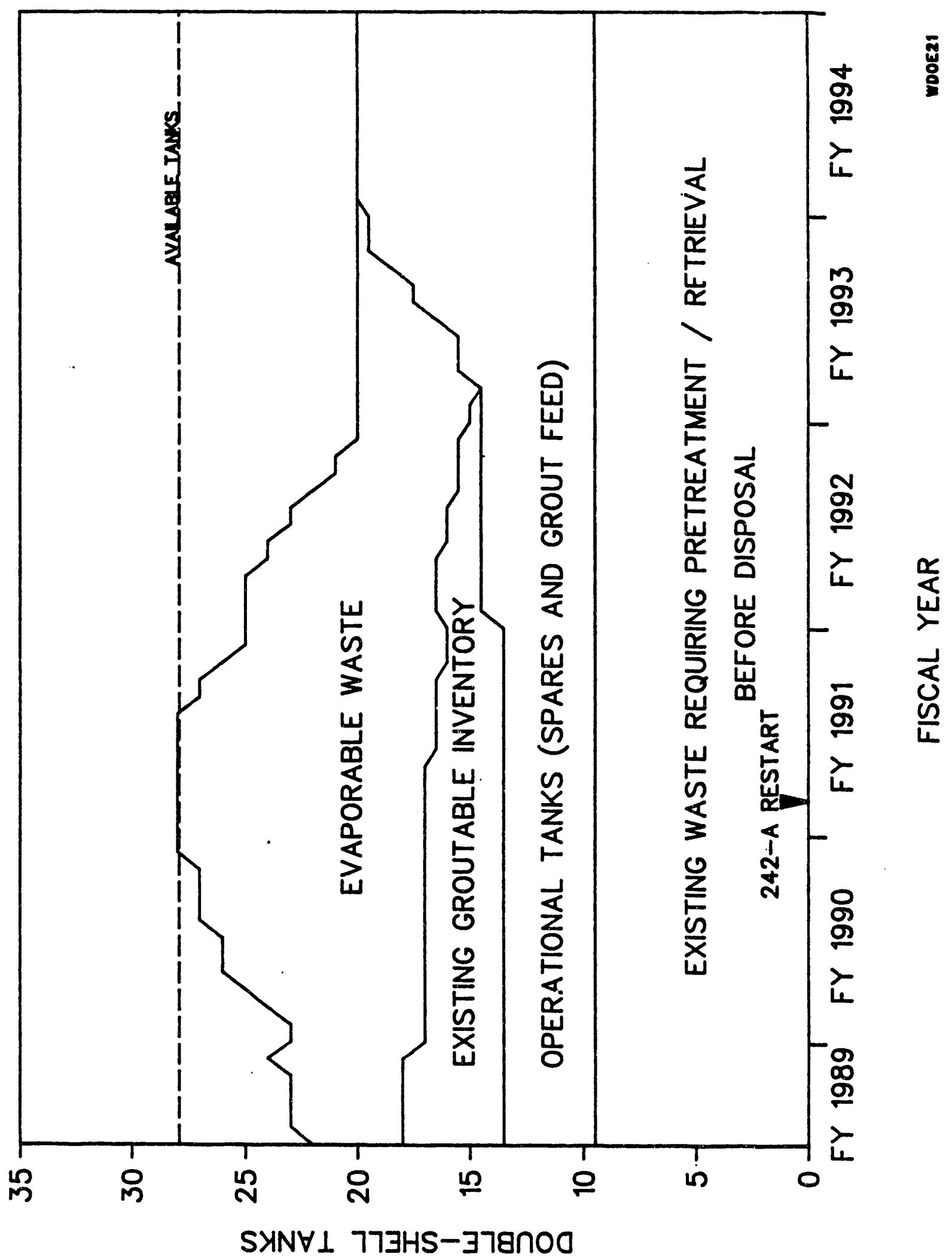


WHC-EP-0286

\subsubsection{Other Cases}

All other cases need not be reexamined with the December 1990 evaporator restart assumption. These cases result in less waste generation than the preceding case (Case 2C) and therefore can be supported. 
WHC-EP-0286

\subsection{REFERENCES}

Strode, J. N., 1989, 1988 Tank Farm Waste Volume Projections, WHC-EP-0197, Westinghouse Hanford Company, Richland, Washington. 
WHC-EP-0286

This page intentionally left blank. 
WHC-EP-0286

\section{APPENDIX_A}

\section{DETAILED CASE ASSUMPTIONS}


WHC-EP-0286

This page intentionally left blank. 


\section{Case 1A Assumptiors}

BASELINE

\section{PUREX}

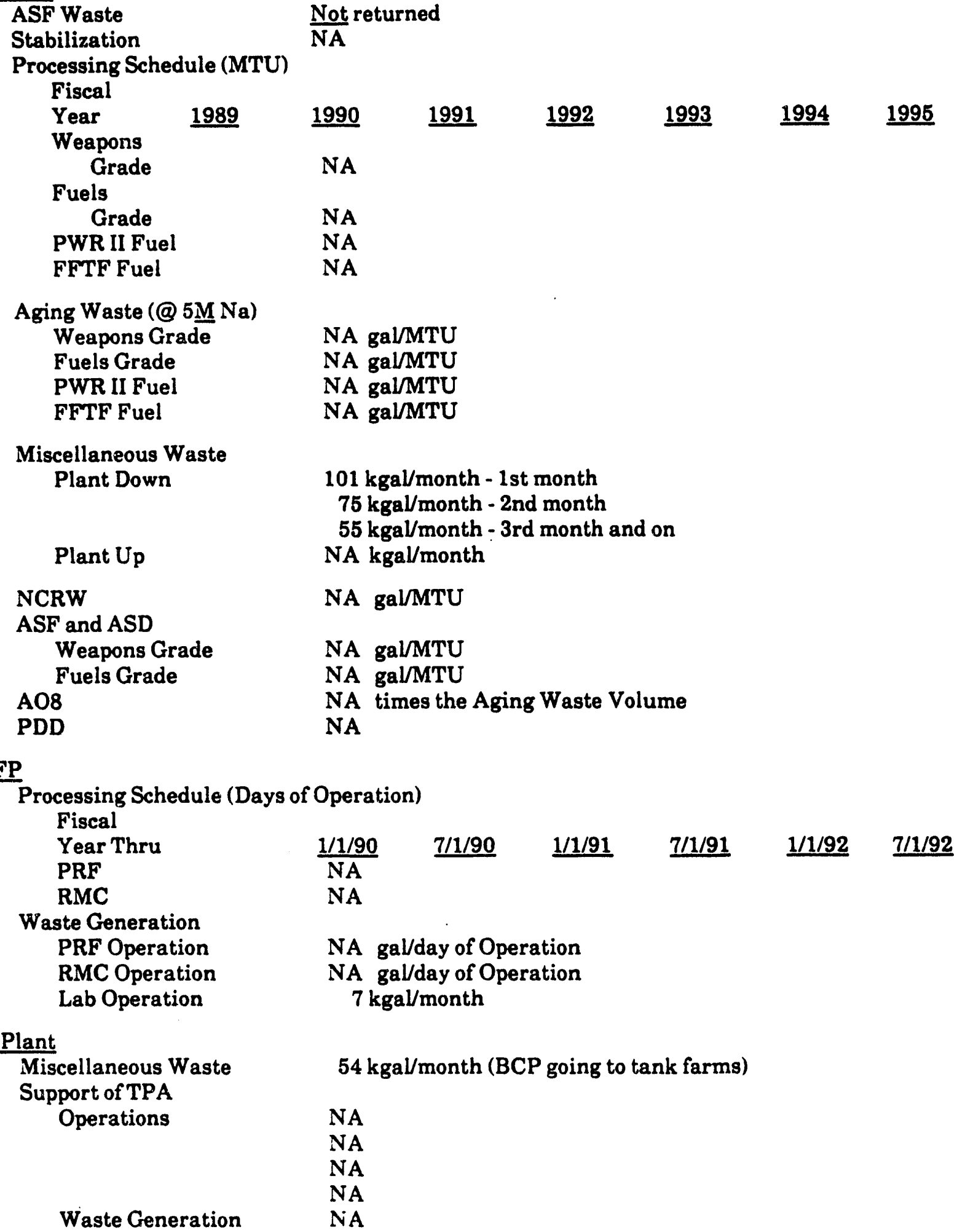


Case 1A Assumptions

BASELINE (Continued)

Evaporator

Restart date

NA

Operations

NA

NA

NA

Grout Treatment Facility (GTF)

Processing Schedule (Vaults filled)

$\begin{array}{lcc}\text { Fiscal } & & \\ \text { Year } & \frac{1988}{0.5} & \frac{198}{0.5} \\ \text { Yearly } & 0.5 & 1 \\ \text { Culm } & 0.5 & 1\end{array}$

$\frac{1989}{0.5}$

1

$\underline{1990}$

$\frac{1991}{2}$

2
3

$\underline{1992}$

$\underline{1993} \quad \underline{1994}$

Culm

$140 \mathrm{kgal} /$ Vault

Waste Generation

- No grouting of dilute waste.

Operations

- No grouting of DSS because of not having retrieval and no retrieval tank available.

- Second grout feed tank required for over 3 vaults per year.

Saltwell Liquid Pumping

Processing Schedule (Tanks Stabilized)

Fiscal

Year

$\underline{1989}$

Yearly

$\underline{1990}$

$\underline{1991}$

$\underline{1992}$

$\underline{1993}$

$\underline{1994}$

$\underline{1995}$

Culm

NA

Porosity

NA

Other Facilities

S Plant Waste

T Plant Waste

100 Area Sulfate

300/400 Area Waste

Tank Farms

All Flushes

$2 \mathrm{kgal} /$ month

$17 \mathrm{kgal} /$ month

$16 \mathrm{kgal} /$ month

$5 \mathrm{kgal} /$ month

$50 \mathrm{kgal} /$ month

$33 \mathrm{kgal} /$ month 


\section{Case 1B Assumptions \\ PUREX CLEANOUT WASTE}

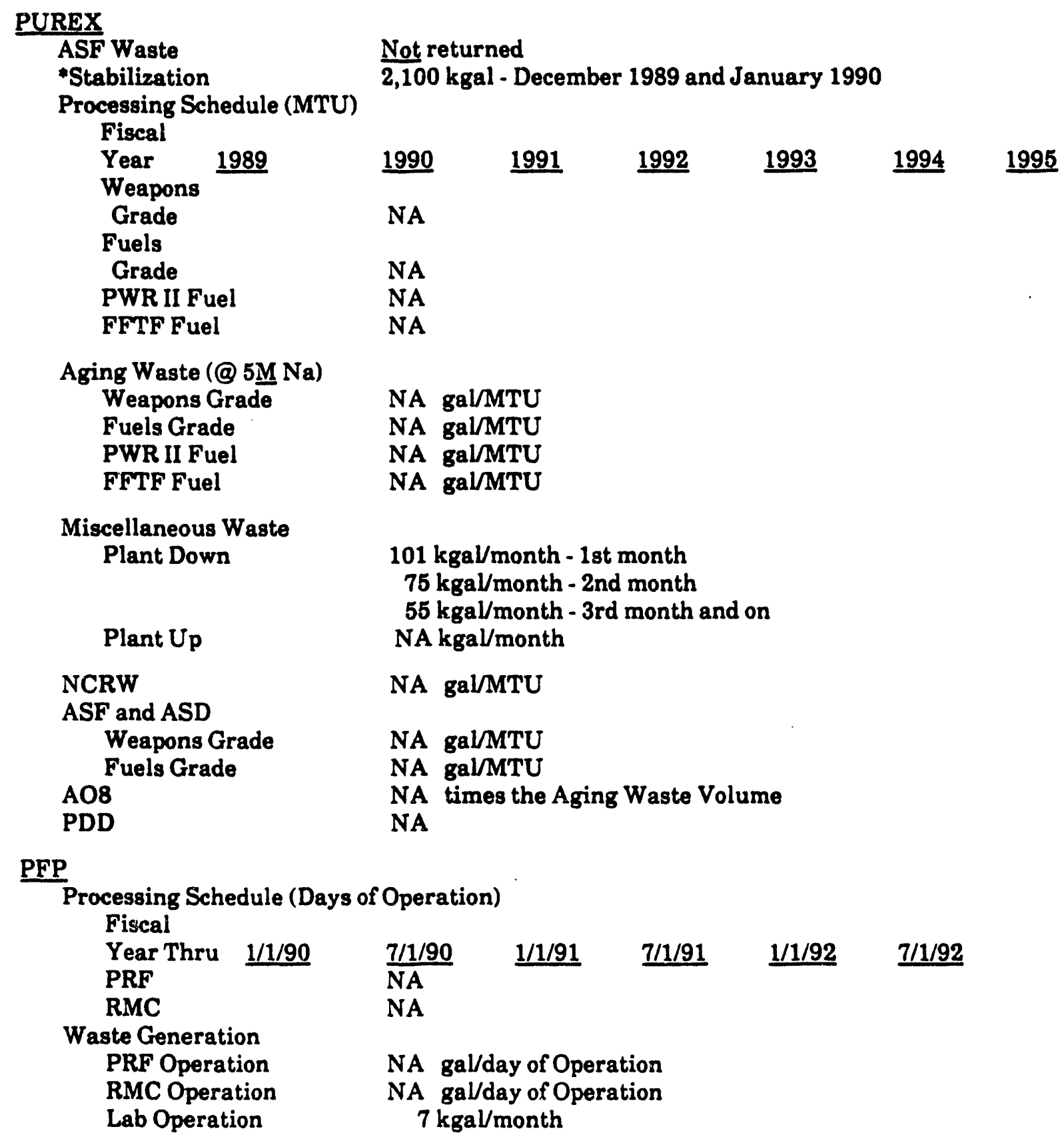

\footnotetext{
*Changed from previous case.
} 
Case 1B Assumptions

PUREX CLEANOUT WASTE (Continued)

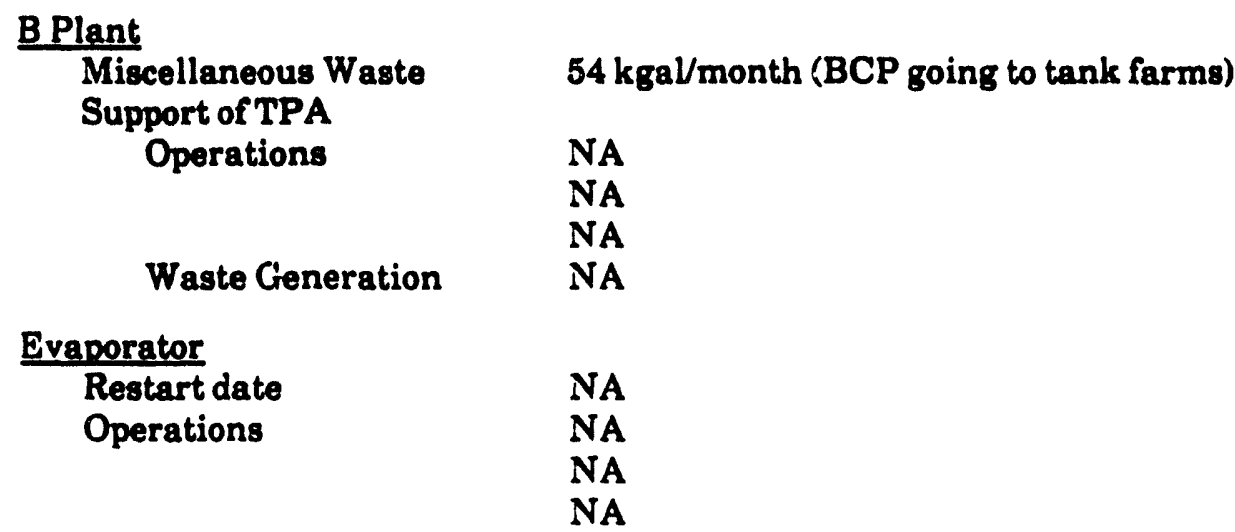

Grout Treatment Facility (GTF)

Processing Schedule (Vaults filled)

$\begin{array}{lccccccc}\text { Fiscal } & & & & & & \\ \text { Year } & 1988 & \frac{1989}{0.5} & \frac{1990}{0} & \frac{1991}{2} & \frac{1992}{3} & \frac{1993}{3} & \frac{1994}{0} \\ \text { Yearly } & 0.5 & 0.5 & 1 & 3 & 6 & 9 & 9 \\ \text { Culm } & 0.5 & 1 & 1 & \end{array}$

Waste Generation

$140 \mathrm{kgal} /$ ault

Operations

- No grouting of dilute waste.

- No grouting of DSS because of not having retrieval and no retrieval tank available.

- Second grout feed tank required for more than 3 vaults per year.

Saltwell Liquid Pumping

Processing Schedule (Tanks Stabilized)

Fiscal

Year

Yearly

$\underline{1989}$

$\underline{1990}$

$\underline{1991}$

$\underline{1992}$

$\underline{1993}$

$\underline{1994}$

Culm

NA

Porosity

NA

\section{Other Facilities}

S Plant Waste

T Plant Waste

$2 \mathrm{kgal} /$ month

$17 \mathrm{kgal} /$ month

$16 \mathrm{kgal} /$ month

100 Area Sulfate

$5 \mathrm{kgal} /$ month

300/400 Area Waste

$50 \mathrm{kgal} /$ month 


\section{Case 1C Assumptions \\ SUPPORT TO TRI-PARTY AGREEMENT}

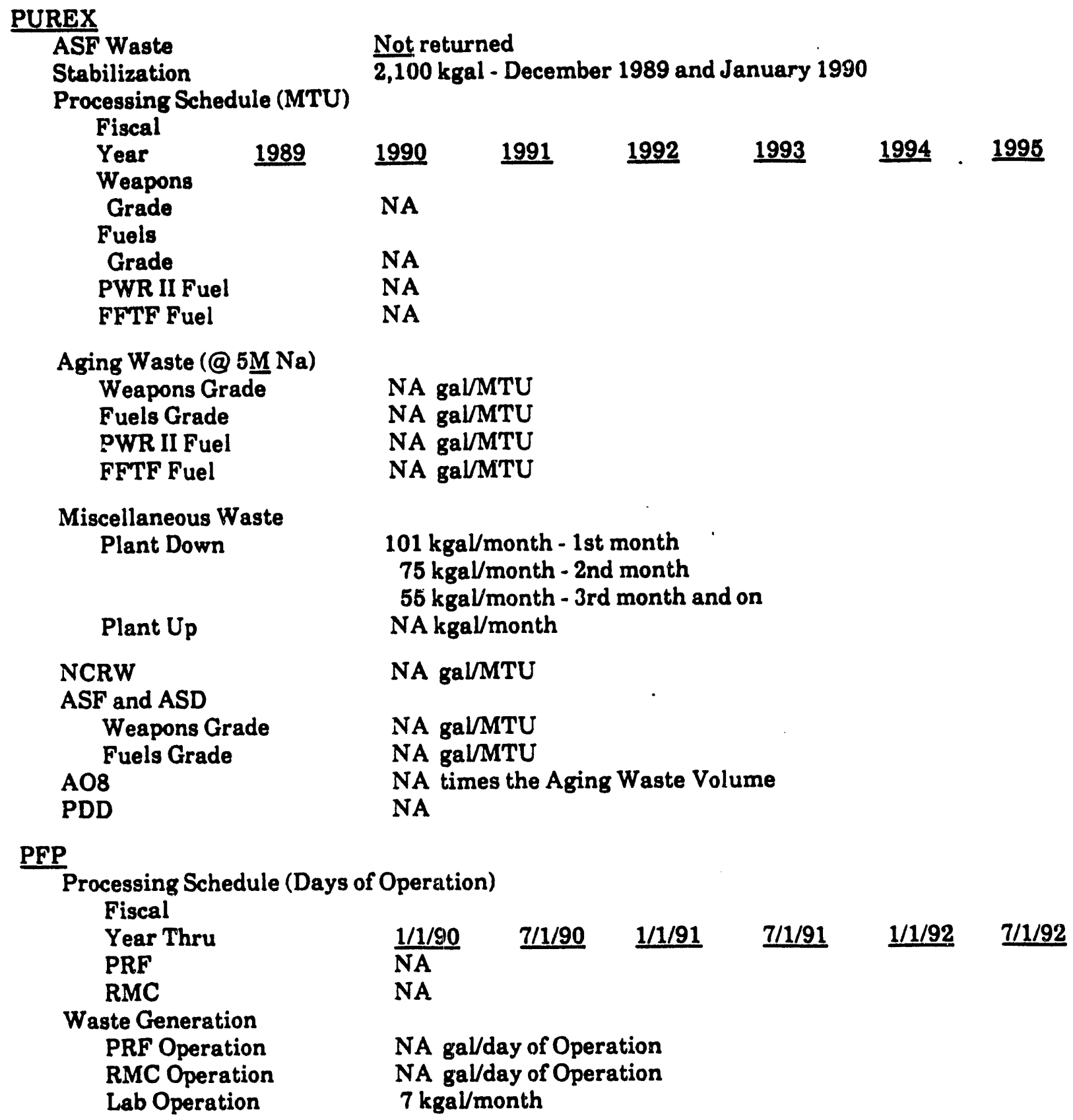




\section{Case 1C Assumptions \\ SUPPORT TO TRI-PARTY AGREEMENT (Continued)}

\section{B Plant}

Miscellaneous Waste

* Support of TPA

Operations

*Waste Generation

Evaporator

Restart date

Operations
$54 \mathrm{kgal} /$ month (BCP going to tank farms)

- Tank 101-AY cleanout 10/91 (2 year before demo)

- Tank 102-AY cleanout 10/92 (1 year before demo)

- Tank 102-AY filled with $600 \mathrm{kgal}$ water 10/93

$2 \mathrm{gal} / 1 \mathrm{gal}$ feed

NA

NA

NA

NA

Grout Treatment Facility (GTF)

Processing Schedule (Vaults filled)

Fiscal

Year

Yearly

Culm

$\begin{array}{cc}\frac{1988}{0.5} & \frac{1989}{0.5} \\ 0.5 & 1\end{array}$
$\underline{1990}$
0
1

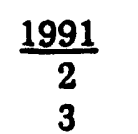
$\frac{1992}{3}$
3
6

$\underline{1993}$

3

$\underline{1994}$

0

$140 \mathrm{kgal} / \mathrm{Vault}$

- No grouting of dilute waste.

- No grouting of DSS because of not having retrieval and no - retrieval tank available.

- Second grout feed tank required for over 3 vaults per year.

Saltwell Liquid Pumping

* Processing Schedule (Tanks Stabilized)

Fiscal

Year 1989

$\underline{1990}$

1991

$\underline{1992}$

$\underline{1993}$

$\underline{1994}$

$\underline{1995}$

Yearly

3

5

9

Culm

3

17

9
26

9

35
9
44

5

$35 \%$

Qther Facilities

S Plant Waste

T Plant Waste

$2 \mathrm{kgal} /$ month

100 Area Sulfate

300/400 Area Waste

Tank Farms

$17 \mathrm{kgal} /$ month

$16 \mathrm{kgal} /$ month

$5 \mathrm{kgal} /$ month

$50 \mathrm{kgal} /$ month

\footnotetext{
"Changed from previous case.
} 


\section{Case 1D Assumptions \\ PFP OPERATION}

\section{PUREX}

ASF Waste

Not returned

Stabilization

2,100 kgal - December 1989 and January 1990

Processing Schedule (MTU)

Fiscal

Year $\underline{1989}$

$\underline{1990}$

$\underline{1991}$

$\underline{1992}$

$\underline{1993}$

$\underline{1994}$

$\underline{1995}$

Weapons

Grade

Fuels

Grade

PWR II Fuel

FFTF Fuel

NA

NA

NA

NA

Aging Waste (@ 5M Na)

Weapons Grade

Fuels Grade

PWR II Fuel

FFTF Fuel

NA. gal/MTU

NA. gal/MTU

N/L gal/MTU

NA gal/MTU

Miscellaneous Waste

Plant Down

$101 \mathrm{kgal} /$ month - $1 \mathrm{st}$ month

$75 \mathrm{kgal} /$ month - 2nd month

Plant Up NA kgal/month

NCRW

ASF and ASD

Weapons Grade NA gai/MTU

Fuels Grade

NA $E^{\mathrm{al} / \mathrm{MTU}}$

NA gai/MTU

NA times the Aging Waste Volume

A08

PDD NA

PFP

* Processing Schedule (Days of Operation)

Fiscal

$\begin{array}{lllllll}\text { Year Thru } & \frac{1 / 1 / 90}{240} & \frac{7 / 1 / 90}{-} & \frac{1 / 1 / 91}{120} & \frac{7 / 1 / 91}{-} & \frac{1 / 1 / 92}{120} & \frac{7 / 1 / 92}{80} \\ \text { PRF } & - & & \end{array}$

RMC

$5 ? \quad 26$

$26 \quad 26$

26

*Waste Generation

PRF Operation

RMC Operation

uab Operation

$1,844 \mathrm{gal} / \mathrm{day}$ of Operation $448 \mathrm{gal} /$ day of Operation

$7 \mathrm{kgal} /$ month

*Changed from previous case. 


\section{Case 1D Assumptions \\ PFP OPERATION (Continued)}

\section{B Plant}

Miscellaneous Waste

Support of TPA

Operations

$54 \mathrm{kgal} /$ month (BCP going to tank farms)

- Tank 101-AY cleanout 10/91 (2 year before demo)

- Tank 102-AY cleanout 10/92 (1 year before demo)

- Tank 102-AY filled with $600 \mathrm{kgal}$ water $10 / 93$

Waste Generation $2 \mathrm{gal} / 1 \mathrm{gal}$ feed

\section{Evaporator}

Restart date NA

Operations NA

NA

NA

Grout Treatment Facility (GTF)

Processing Schedule (Vaults filled)

\begin{tabular}{|c|c|c|c|c|c|c|c|}
\hline Year & $\frac{1988}{1}$ & 1989 & $\underline{1990}$ & $\underline{1991}$ & $\underline{1992}$ & $\underline{1993}$ & $\underline{1994}$ \\
\hline Yearly & 0.5 & 0.5 & 0 & 2 & 3 & 3 & 0 \\
\hline Culm & 0.5 & 1 & 1 & 3 & 6 & 9 & 9 \\
\hline
\end{tabular}

Waste Generation

$140 \mathrm{kgal} /$ Vault

Operations

- No grouting of dilute waste.

- No grouting of DSS because of not having retrieval and no retrieval tank available.

- Second grout feed tank required for over 3 vaults per year.

Saltwell Liquid Pumping

Processing Schedule (Tanks Stabilized)

Fiscal

Year

Yearly

Culm

$\frac{1989}{3}$

$\frac{1990}{5}$
8

$\frac{1991}{9}$
17

$\frac{1992}{9}$
.26

$\frac{1993}{9}$
35

Porosity

$35 \%$

Other Facilities

S Plant Waste

$T$ Plant Waste

$2 \mathrm{kgal} /$ month

100 Area Sulfate

$17 \mathrm{kgal} /$ month

300/400 Area Waste

$16 \mathrm{kgal} /$ month

$5 \mathrm{kgal} / \mathrm{month}$

Tank Farms

$50 \mathrm{kgal} /$ month

\footnotetext{
*Changed from previous case.
} 


\section{Case IE Assumptions PUREX FACILITY OPERATION}

\section{PUREX}

ASF Waste

Stabilization

*Processing Schedule (MTU)

Fiscal

Year

Weapons

Grade

Fuels

Grade

PWR II Fuel

FFTF Fuel

*Aging Waste (@ 5ㅆ Na)

Weapons Grade

Fuels Grade

PWR II Fuel

FFTF Fuel

*Miscellaneous Waste

Plant Down

Plant Up

*NCRW

*ASF and ASD

Weapons Grade

*A08

Fuels Grade

*PDD
Not returned

2,100 kgal - December 1989 and January 1990

19

$332 \quad 187$

380

500

500

430

$\underline{1993}$

$\underline{1994}$

$\underline{1995}$

380

500

48

1,366
$281 \mathrm{gal} / \mathrm{MTU}$

$245 \mathrm{gal} / \mathrm{MTU}$

$245 \mathrm{gal} / \mathrm{MTU}$

$58 \mathrm{gal} / \mathrm{MTU}$

$101 \mathrm{kgal} /$ month - $1 \mathrm{st}$ month

$75 \mathrm{kgal} /$ month - 2nd month

$55 \mathrm{kgal} /$ month - 3rd month and on

$124 \mathrm{kgal} /$ month (69 kgal/month more than standby)

$1,664 \mathrm{gal} / \mathrm{MTU}$

4,500 gal/MTU (prior to ammonia destruction)

$350 \mathrm{gal} / \mathrm{MTU}$ (after ammonia destruction)

6 times the Aging Waste Volume

(Sent to tank farms)

Not sent to DSTs after cleanout

PFP

Processing Schedule (Days of Operation)

Fiscal

Year Thru $1 / 1 / 90$

7/1/90

PRF $\quad \frac{1 / 190}{240}$

RMC

$\overline{52}$

$\frac{1 / 1 / 91}{120}$

7/1/91

$\frac{1 / 1 / 92}{120}$

$\underline{7 / 1 / 92}$

$\overline{26}$

26

80

26

Waste Generation

PRF Operation

RMC Operation

Lab Operation

$1,344 \mathrm{gal} /$ day of Operation

$448 \mathrm{gal} /$ day of Operation

$7 \mathrm{kgal} /$ month

\footnotetext{
*Changed from previous case.
} 


\section{Case tE Assumptions PUREX FACILITY OPERATION (Continued)}

\section{B Plant}

Miscellaneous Waste

Support of TPA

Operations

Waste Generation

Evaporator

$\begin{array}{ll}\text { Restart date } & \text { NA } \\ \text { Operations } & \text { NA } \\ & \text { NA } \\ & \text { NA }\end{array}$

Grout Treatment Facility (GTF)

Processing Schedule (Vaults filled)

Fiscal

Year

Yearly

Culm

Operations
NA

NA

NA
$54 \mathrm{kgal} /$ month (BCP going to tank farms)

- Tank 101-AY cleanout 10/91 (2 year before demo)

- Tank 102-AY cleanout 10/92 (1 year before demo)

- Tank 102-AY filled with $600 \mathrm{kgal}$ water $10 / 93$

2 gal/1 gal feed

$\begin{array}{lllllll}1988 & \frac{1989}{0.5} & \frac{1990}{0} & \frac{1991}{2} & \frac{1992}{3} & \frac{1993}{4} & \frac{1994}{0} \\ 0.5 & 1 & 1 & 3 & 6 & 10 & 12\end{array}$

- No grouting of dilute waste.

- No grouting of DSS because of not having retrieval and no retrieval tank available.

- Second grout feed tank required for over 3 vaults per year.

Saltwell Liquid Pumping

Processing Schedule (Tanks Stabilized)

Fiscal

Year

Yearly

$\frac{1989}{3}$

$\underline{1990}$

5

$\frac{1991}{9}$

$\frac{1992}{9}$

$\frac{1993}{9}$

$\frac{1994}{9}$

$\frac{1995}{5}$

Culm

$35 \%$

Other Facilities

S Plant Waste

T Plant Waste

100 Area Sulfate 300/400 Area Waste

Tank Farms

$2 \mathrm{kgal} / \mathrm{month}$

$17 \mathrm{kgal} /$ month

$16 \mathrm{kgal} /$ month

$5 \mathrm{kgal} /$ month

$50 \mathrm{kgal} /$ month 


\section{Case 2A Assumptions \\ PUREX FACILITY OPERATION / EVAP RESTART}

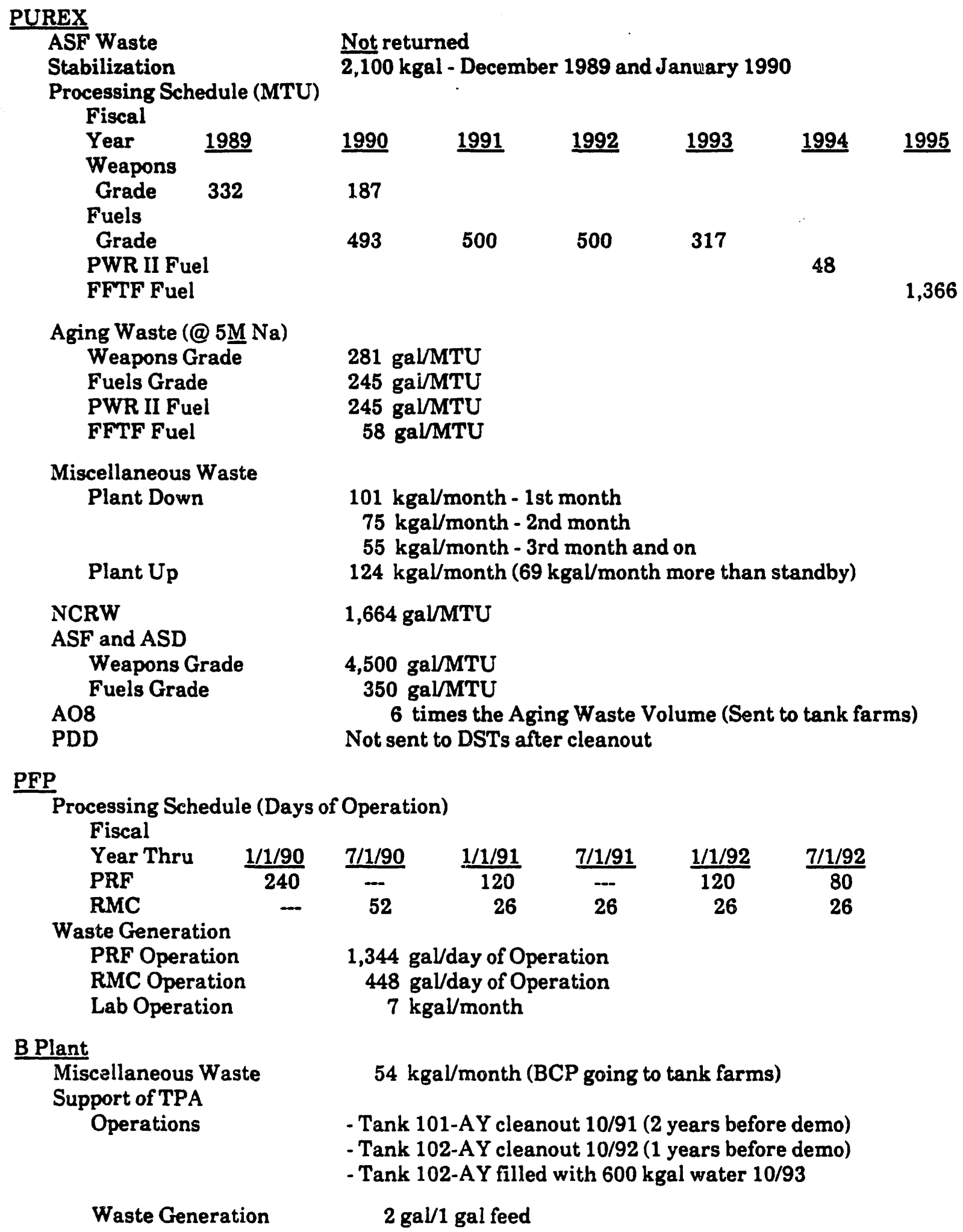


Case 2A Assumptions

PUREX FACILITY OPERATION / EVAP RESTART (Continued)

Evaporator

*Restart date

$12 / 90$

* Operations

- Ramp up to $1,000 \mathrm{kgal} / \mathrm{month}$ in steps of $250 \mathrm{kgal} / \mathrm{month}$.

- The evaporator will continue operation until all dilute inventory is processed and then will be down for 11 months for upgrades.

- After upgrades are completed the evaporator will ramp up to 1,000 $\mathrm{kgal} /$ month in steps of $250 \mathrm{kgal} /$ month.

Grout Treatment Facility (GTF)

*Processing Schedule (Vaults filled)

Fiscal

Year

Yearly

$\frac{1988}{0.5}$

$\underline{1989}$

0.5
$\underline{1990}$
0
1

Culm

0.5

1

$\begin{array}{cr}\frac{1991}{2} & \frac{1992}{3} \\ 3 & 6\end{array}$

$\underline{199}$

$\frac{1994}{4}$

10

14

Waste Generation

$140 \mathrm{kgal} /$ Vault

Operations

- No grouting of dilute waste.

- No grouting of DSS because of not having retrieval and no retrieval tank available.

- Second grout feed tank required for over 3 vaults per year.

Saltwell Liquid Pumping

Processing Schedule (Tanks Stabilized)

Fiscal

Year

Yearly

$\underline{1989}$

3

$\underline{1990}$

5

$\frac{1991}{9}$

$\frac{1992}{9}$

17

26

$\frac{1993}{9}$
35

$\underline{1994}$

$\underline{1995}$

Porosity

$35 \%$

Other Facilities

S Plant Waste

T Plant Waste

$2 \mathrm{kgal} /$ month

100 Area Sulfate

$17 \mathrm{kgal} /$ month

$16 \mathrm{kgal} / \mathrm{month}$

$5 \mathrm{kgal} /$ month

$300 / 400$ Area Waste

$50 \mathrm{kgal} /$ month

\footnotetext{
*Changed from previous case.
} 


\section{Case 2B Assumptions \\ PFP OPERATION / EVAP RESTART}

\section{PUREX}

ASF Waste

Not returned

Stabilization

2,100 kgal - December 1989 and January 1990

*Processing Schedule (MTU)

Fiscal

Year

$\underline{1989}$

$\underline{1990}$

$\underline{1991}$

$\underline{1992}$

$\underline{1993}$

1994

$\underline{1995}$

Weapons

Grade

NA

Fuels

Grade

NA

PWR II Fuel

FFTF Fuel

NA

NA

*Aging Waste (@ 5M Na)

Weapons Grade

NA gal/MTU

Fuels Grade

NA gal/MTU

PWR II Fuel

NA galMTU

FFTF Fuel

NA gal/MTU

* Miscellaneous Waste

Plant Down

$101 \mathrm{kgal} /$ month - 1st month

$75 \mathrm{kgal} /$ month - 2nd month

Plant Up

$55 \mathrm{kgal} / \mathrm{month}-3 \mathrm{rd}$ month and on

*NCRW

*ASF and ASD

NA kgal/month

NA gal/MTU

Weapons Grade

NA gal/MTU

Fuels Grade

NA gal/MTU

NA times the Aging Waste Volume

*A08

NA

PFP

Processing Schedule (Days of Operation)

Fiscal

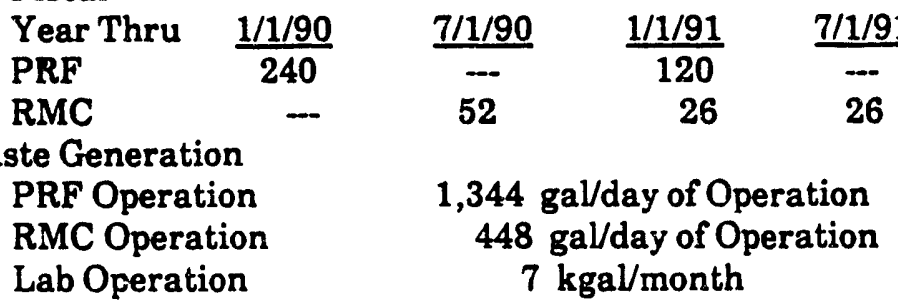

\footnotetext{
*Changed from previous case.
} 


\section{Case 2B Assumptions \\ PFP OPERATION / EVAP RESTART (Continued)}

\section{B Plant}

Miscellaneous Waste

Support of TPA

Operations

Waste Generation

Evaporator

Restart date

Operations

\section{$54 \mathrm{kgal} /$ month (BCP going to tank farms)}

- Tank 101-AY cleanout 10/91 (2 year before demo)

- Tank 102-AY cleanout 10/92 (1 year before demo)

- Tank 102-AY filled with $600 \mathrm{kgal}$ water $10 / 93$

$2 \mathrm{gal} / 1$ gal feed

$12 / 90$

- Ramp up to $1,000 \mathrm{kgal} / \mathrm{month}$ in steps of $250 \mathrm{kgal} / \mathrm{month}$.

- The evaporator will continue operation until all dilute inventory is processed and then will be down for 11 months for upgrades.

- After upgrades are completed the evaporator will ramp up to 1,000 $\mathrm{kgal} /$ month in steps of $250 \mathrm{kgal} /$ month.

Grout Treatment Facility (GTF)

Processing Schedule (Vaults filled)

Fiscal

Year

Yearly

$\frac{1988}{0.5} \quad \frac{1989}{0.5}$

$\frac{1990}{0}$

1

$\begin{array}{cc}\frac{1991}{2} & \frac{1992}{3} \\ 3 & 6\end{array}$

$\underline{1993}$

$\underline{1994}$

Culm

0.5

$140 \mathrm{kgal} /$ Vault

Waste Generation

- No grouting of dilute waste.

Operations

- No grouting of DSS because of not having retrieval and no retrieval tank available.

- Second grout feed tank required for over 3 vaults per year.

Saltwell Liquid Pumping

Processing Schedule (Tanks Stabilized)

Fiscal

Year

Yearly

$\frac{1989}{3}$
3

$\frac{1990}{5}$

$\frac{1991}{9}$

$\frac{1992}{9}$

$\frac{1993}{9}$

$\frac{1994}{9}$

$\underline{1995}$

Culm

8

17

35

44

49

Porosity

$35 \%$

Other Facilities

S Plant Waste

T Plant Waste

$2 \mathrm{kgal} /$ month

100 Area Sulfate

$17 \mathrm{kgal} /$ month

$16 \mathrm{kgal} /$ month

300/400 Area Waste

$5 \mathrm{kgal} /$ month

Tank Farms

$50 \mathrm{kgal} /$ month 


\section{Case 2C Assumptions \\ MODIFIED PRODUCTION FACILITY \\ OPERATION / EVAP RESTART}

\section{PUREX}

ASF Waste

Not returned

"Stabilization

2,100 kgal - December 1989 and January 1990

*Processing Schedule (MTU)

Fiscal

Year

1989

$\underline{1990}$

$\underline{1991}$

$\underline{1992}$

$\underline{1993}$

$\underline{1994}$

$\underline{1995}$

$\underline{1996}$

Weapons

144

$0 \quad 3751$

Fuels

Grade

PWR II Fuel

FFTF Fuel

$\begin{array}{lllll}70 & 500 & 500 & 500 & 240\end{array}$

48

797

569

*Aging Waste (@ 5M Na)

Weapons Grade

Fuels Grade

$281 \mathrm{gal} / \mathrm{MTU}$

$245 \mathrm{gal} / \mathrm{MTU}$

$245 \mathrm{gal} / \mathrm{MTU}$

PWR II Fue

$58 \mathrm{gal} / \mathrm{MTU}$

*Miscellaneous Waste

Plant Down

$101 \mathrm{kgal} /$ month - $1 \mathrm{st}$ month

$75 \mathrm{kgal} /$ month - 2nd month

$55 \mathrm{kgal} /$ month - $3 \mathrm{rd}$ month and on

Plant Up

$124 \mathrm{kgal} /$ month (69 kgal/month more than standby)

*NCRW

*ASF and ASD

Weapons Grade

$1,664 \mathrm{gal} / \mathrm{MTU}$

$3501 \mathrm{gal} / \mathrm{MTU}$

$350 \mathrm{gal} / \mathrm{MTU}$

A08

6 times the Aging Waste Volume

PFP

"Processing Schedule (Days of Operation)

Fiscal

$\begin{array}{lllllll}\text { Year Thru } & \frac{1 / 1 / 90}{0} & \frac{7 / 1 / 90}{40} & \frac{1 / 1 / 91}{60} & \frac{7 / 1 / 91}{40} & \frac{1 / 1 / 92}{60} & \frac{7 / 1 / 92}{40}\end{array}$

RMC

0
0

$\begin{array}{lll}40 & 60 & 40 \\ 40 & 60 & 40\end{array}$

$60 \quad 40$

*Waste Generation

PRF Operation

RMC Operation

Lab Operation
$1,344 \mathrm{gal} /$ day of Operation
$448 \mathrm{gal} /$ day of Operation
$7 \mathrm{kgal} / \mathrm{month}$

* Changed from the previous case.

1 Weapons Grade processing occurs after the ammonia destruction process is in place. 


\section{Case 2C Assumptions \\ MODIFIED PRODUCTION FACILITY \\ OPERATION / EVAP RESTART \\ (Continued)}

\section{B Plant}

Miscellaneous Waste

Support of TPA

Operations

Waste Generation

Evaporator

Restart date

Operations

\section{$54 \mathrm{kgal} /$ month (BCP going to tank farms)}

- Tank 101-AY cleanout 10/91 (2 year before demo)

- Tank 102-AY cleanout 10/92 (1 year before demo)

- Tank 102-AY filled with $600 \mathrm{kgal}$ water $10 / 93$

$2 \mathrm{gal} / 1 \mathrm{gal}$ feed

$12 / 90$

- Ramp up to $1,000 \mathrm{kgal} / \mathrm{month}$ in steps of $250 \mathrm{Kgal} / \mathrm{mo}$.

- The evaporator will continue operation until all dilute inventory is processed and then will be down for 11 months for upgrades.

- After upgrades are completed the evaporator will ramp up to $1,000 \mathrm{kgaV} /$ month in steps of $250 \mathrm{kgaV} /$ month.

Grout Treatment Facility (GTF)

*Processing Schedule (Vaults filled)

Fiscal

Year

Yearly

$\frac{1988}{0.5} \quad \frac{1989}{0.5}$

0.5

$\frac{1990}{0}$

$\frac{1991}{2}$
3

$\frac{1992}{3}$

$\begin{array}{cc}\frac{1993}{4} & \frac{1994}{4} \\ 10 & 14\end{array}$

Waste Generation

$140 \mathrm{kgal} /$ Vault

Operations

- No grouting of dilute waste.

- No grouting of DSS because of not having retrieval and no retrieval tank available.

- Second grout feed tank required for over 3 vaults per year.

Saltwell Liquid Pumping

Processing Schedule (Tanks Stabilized)

Fiscal

Year

Yearly

$\frac{1989}{3}$

$\underline{1990}$

$\frac{1991}{9}$

$\frac{1992}{9}$

$\frac{1993}{9}$

$\underline{1994}$

$\underline{1995}$

Culm

8

17

26

35

44

Porosity

$35 \%$

Other Facilities

S Plant Waste

$T$ Plant Waste

$2 \mathrm{kgal} /$ month

100 Area Sulfate

$17 \mathrm{kgal} /$ month

300/400 Area Waste

$16 \mathrm{kgal} /$ month

Tank Farms

$5 \mathrm{kgal} /$ month

$50 \mathrm{kgal} /$ month

\footnotetext{
*Changed from the previous case.
} 

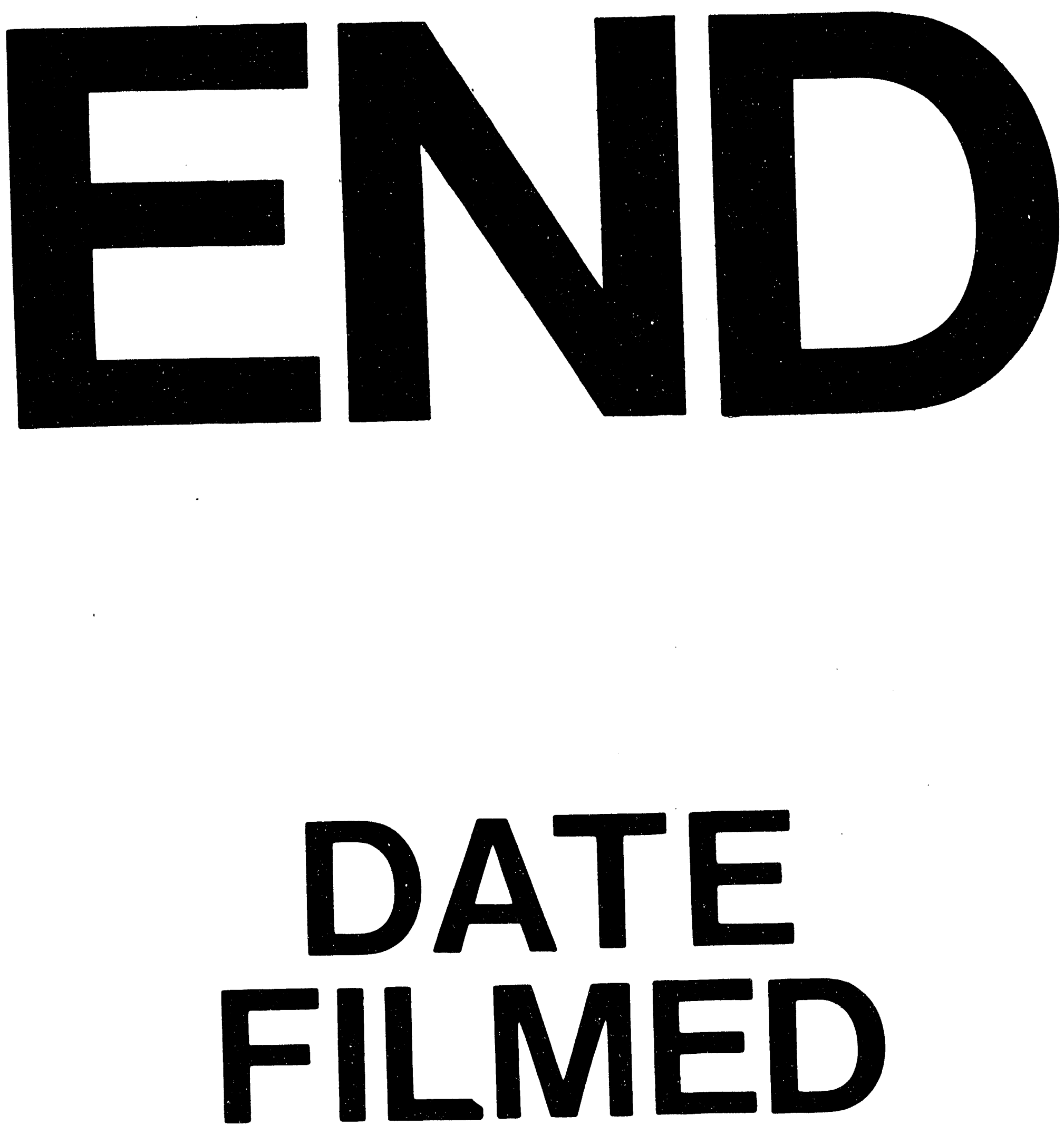

1

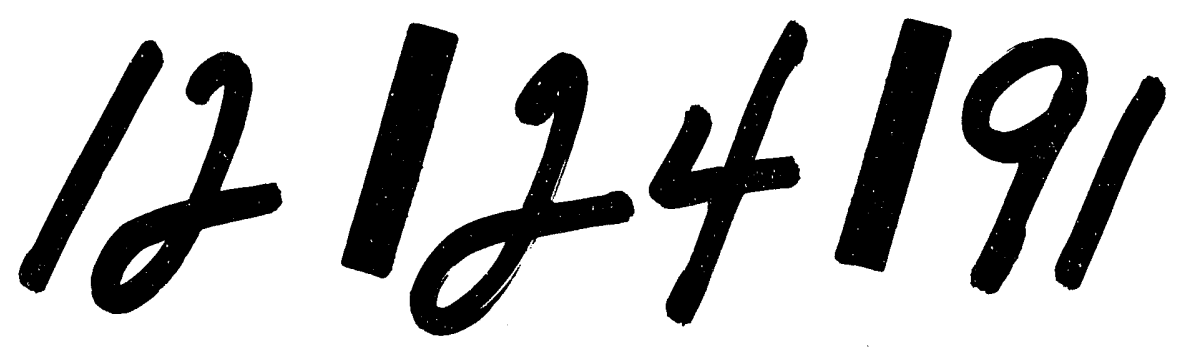




$$
\text { }
$$

